\title{
超高層建物におけるオフイス内の家具群の地震時挙動シミュレーション SIMULATION FOR SEISMIC BEHAVIOR OF OFFICE FURNITURE IN A HIGH-RISE BUILDING
}

\author{
正月俊行*, 翠川三郎**, 大堀 道広***, 三浦弘 之 之** $^{* *}$ \\ Toshiyuki MASATSUKI, Saburoh MIDORIKAWA, Michihiro OHORI \\ and Hiroyuki MIURA
}

\begin{abstract}
Seismic behavior of office furniture is examined in an upper floor of a high-rise building due to long period and large amplitude motion by a rigid body simulation technique. Dynamic parameters of the furniture used in the simulation such as friction, spring and damper coefficients are determined from comparison of the computed behavior with the behavior in the shaking table tests. The simulation results show that the furniture continues to move around and collide against each other. The behavior of the furniture can cause fear and injury to people in the floor, and make the evacuation action difficult.
\end{abstract}

Keywords : Behavior of furniture, Long-period motion, High-rise building, Shaking table test, Rigid body simulation 家具の挙動，長周期地震動，超高層建物，振動実験，剛体の物理シミュレーション

\section{1. はじめに}

近年の地震では、全負傷者の内、屋内における家具類の転倒、落下物 による原因が占める割合が 4 割程度であることが知られており 、屋内での 人的被害を考える上で、地震時の家具類の挙動について検討することは 重要である。また、近年発生が懸念されている東海, 東南海, 南海地震の 巨大地震では長周期地震動が卓越すると考えられ、大都市圈に数多く存 在する長い固有周期を持つ超高層建物では大きな摇れが数分間続くこと が予測されている 2)。そのため、長周期地震動による超高層ビル内での家 具類の転倒や移動に対する検討が必要とされる。

家具類の挙動については、今までにも被害調査や解析に基づいて多く の研究が行われ(列えば、3)-6)、地震動強さと転倒率の関倸などが整理されてき た。これら既往の研究では、一般建物で生ずるような周波数 $1 \sim 2 \mathrm{~Hz}$ 程度 の摇れに対する家具類の転倒やロッキングの举動に重点が置かれていた。 しかし、超高層建物上階で生じるような長周期の摇れによる家具類の移動 などについては検討がほとんどなされていない。

超高層ビルのオフィスでは背の高いキャビネットは固定されている場合 が多いが、デスクや背の低いキャビネット、コピー機等は固定されていない 場合が多い。このような家具類は超高層建物上階で生じる継続時間が長く 長周期・大振幅の摇れにより、転倒しなくとも、大きく移動して人的被害や
混乱を引き起こす可能性が考えられる。特に、キャスター付の家具類は移 動量が大きくなると予想されるが、これらの挙動について検討した例は見 当たらない。

本研究では、超高層建物上階のオフィスを対象として、固定されていな いデスクやキャビネット等の家具類の地震時挙動を振動実験および㓮体の 物理シミュレーションを用いて検討を行なう。まず、長周期・大振幅の摇れ における家具類の挙動を把握するため、長周期振動台を用いた振動実験 を行なう。次に、剖体の物理シミュレーションプログラムを用いて、振動実験 をシミュレートし、実験結果を説明できるパラメータ(摩擦係数など)を設定 する。最後に、一般的なオフィスレイアウトをシミュレーション上で再現し、 超高層建物上階における家具群の挙動について検討する。

\section{2. 振動実験 \\ 2.1 実験概要}

振動実験には大変位 2 次元振動台を用いた。この振動台は大振幅で加 振することができ、最大変位は長軸が土 $100 \mathrm{~cm}$ 、短軸が士 $50 \mathrm{~cm}$ となってい る。最大加速度は $1000 \mathrm{gal}$ 、最大速度は 150kine である。また、台の大きさ は約 $3 \mathrm{~m} \times$ 約 $2.5 \mathrm{~m}$ である。振動実験に用いた試験体を表 1 に示す。床材 はプライウッドとタイルカーペットの 2 種類を用い、試験体 7 種類に対して計

\footnotetext{
* 東京工業大学総合理工学研究科人間環境システム専攻 大学院生 (研究当時)

** 東京工業大学総合理工学研究科人間環境システム専攻 教授・工博

*** 東京工業大学都市地震工学センター 研究員・工博

**** 東京工業大学都市地震工学センター COE研究員 $\cdot$ 博士 (工学)
}

Graduate Student, Dept. of Built Environment, Tokyo Institute of Technology

Prof., Dept. of Built Environment, Tokyo Institute of Technology, Dr. Eng.

Research Fellow, CUEE, Tokyo Institute of Technology, Dr. Eng.

Post Doctoral Research Fellow, CUEE, Tokyo Institute of Technology, Dr. Eng. 
14 種類の組み合わせで実験を行なった。

単純な木箱は後述の物理シミュレーションプログラムで基本となる剛体 に相当するもので、後述する床材のパラメータを設定する際に重要となるも のである。収納棚，デスクは使用している状態を想定してそれぞれ $100 \mathrm{~kg}$ 、 $26 \mathrm{~kg}$ のおもりを中に入れた。キャスター付椅子は、人が座っている状況を 想定して $50 \mathrm{~kg}$ のおもりを載せた場合でも実験を行なった。キャスター付家 具は、単純な木箱に $80 \mathrm{~kg}$ のおもりを入れ、その底面の 4 隅にキャスターを 取り付けた試験体で、コピー機を想定している。 4 ヶ所のキャスターのうち 2 ケ所を固定して加振を行なった。椅子付デスクは、人が摇れを感じた時に 椅子に座ったままデスクにしがみついた場合を想定して、デスク天板と $50 \mathrm{~kg}$ のおもりを載せた椅子を固定した試験体である。

加振は 1 方向の正弦波加振で、床材と試験体の各組み合わせに対して それぞれ表 2 に示すような加振ケースで実験を行なった。超高層建物上階 の摇れを想定して、加振周期は2秒〜 5 秒とした。加速度、速度、変位の最 大值は振動台の性能限界から設定した。キャスターの有無で移動量が大 きく異なるため、加振ケースはキャスターが付いているものとそうでないもの で別々に設定した。ただし、キャスターが付いている試験体でも移動量が 小さかった場合は、キャスター無の加振ケースも行った。なお、加振の順番 は、表 2 の記載順と同一で、キャスター無の場合には加速度の低い順に、 キャスター有の場合には変位の低い順(変位が同じ場合は周期の短い順) とした。

\section{2 実験秸果}

\section{2.1 椅子付デスク}

振動実験で特徵的な挙動がみられた床材がタイルカーペットの場合に

表 1 試験体

\begin{tabular}{|c|c|c|}
\hline 試験体 & 寸法 $[\mathrm{cm}]$ & 総重量 $[\mathrm{kg}]$ \\
\hline 単純な木箱 & $120 \times 60 \times 60$ & 30 \\
\hline 収納棚 & $45 \times 90 \times 110$ & 130 \\
\hline $\begin{array}{c}\text { デスク } \\
\begin{array}{c}\text { キャスー付椅子 } \\
\text { (おるり無) }\end{array}\end{array}$ & $120 \times 70 \times 70$ & 67 \\
\hline $\begin{array}{c}\text { キャスター付椅子 } \\
\text { (おもり有) }\end{array}$ & $60 \times 60 \times 70$ & 12 \\
\hline キャスター付家具 & $60 \times 60 \times 70$ & 60 \\
\hline 椅子付デスク & $120 \times 100 \times 70$ & 110 \\
\hline \multicolumn{2}{|c|}{} & \\
\hline
\end{tabular}

\section{表 2 加振ケース}

キャスター無

\begin{tabular}{|c|c|c|c|c|}
\hline ケース & 周期[sec] & 加速度[gal] & 速度[kine] & 変位[cm] \\
\hline $\mathrm{A} 1$ & 5 & 157.9 & 125.7 & 100 \\
\hline $\mathrm{A} 2$ & 2 & 197.4 & 62.8 & 20 \\
\hline $\mathrm{A} 3$ & 3 & 219.3 & 104.7 & 50 \\
\hline $\mathrm{A} 4$ & 2.5 & 252.7 & 100.5 & 40 \\
\hline $\mathrm{A} 5$ & 3 & 311.4 & 148.7 & 71 \\
\hline $\mathrm{A} 6$ & 2.5 & 372.7 & 125.7 & 59 \\
\hline $\mathrm{A} 7$ & 2 & 394.8 & 125.7 & 40 \\
\hline $\mathrm{A} 8$ & 2 & 463.8 & 147.7 & 47 \\
\hline
\end{tabular}

キャスター有

\begin{tabular}{|c|c|c|c|c|}
\hline ケース & 周期[sec] & 加速度[gal] & 速度[kine] & 変位 $[\mathrm{cm}]$ \\
\hline B1 & 2.5 & 126.3 & 50.3 & 20 \\
\hline B2 & 3 & 87.7 & 41.9 & 20 \\
\hline B3 & 3 & 131.6 & 62.9 & 30 \\
\hline B4 & 5 & 142.1 & 113.0 & 90 \\
\hline
\end{tabular}

おける椅子付デスクの実験結果について述べる。椅子付デスクは長辺方 向と短辺方向の 2 種類加振を行なったが、ここでは短辺方向の加振結果を 示す。図1に椅子付デスクの試験体の設置位置を示す。手前側にデスクの 引き出しがある。試験体の移動と回転量を測るために、振動台奥側と手前 側の両方で振動台に対する相対変位を計測した。

デスク単体では最も加速度の大きいケース A8(入力加速度 464gal)でも 移動しなかったが、椅子付デスクは長辺方向の加振で加速度 253gal 以上, 短辺方向の加振で加速度 $311 \mathrm{gal}$ 以上のケースで移動が見られたここのこ， とから、人がキャスターの椅子に座ったまま机にしがみついた場合を想定 すると、より小さい加速度でも移動するようになることがわかる。図 2 に椅子 付デスクを短辺方向に加振した場合のケースA7 の実験結果を示す。上段 が振動台の加速度波形で、下段が試験体の振動台に対する相対変位で ある。実線および破線は、それぞれ奥側および手前側の変位センサーによ る変位を表している。図を見ると、デスクの引き出し側を中心におもり付椅 子に振り回されるように回転しながら移動しているのがわかる。なお、移動 し始める際には椅子に引っぱられてデスクの天板がたわんでデスクがやや 浮き上がっている様子が見られた。

\section{2.2 キャスター付家具}

次に、床材がタイルカーペットの場合におけるキャスター付家具の加振 結果について述べる。キャスター付家具では、4つのキャスターのうち片側 2 つにストッパーをかけた。また、図 3 のようにキャスターにストッパーがかけ られている辺が、加振方向に対して直交する場合と平行な場合の 2 種類行 なった。図の上段がストッパーのかけられている辺が加振方向に対して直 交する場合で、下段が平行の場合である。図 4 に、ストッパーがかけられて いる辺が加振方向に対して直交の場合におけるキャスター付家具の実験 結果を示す。図を見ると、負の方向(ストッパーをかけた側に対して逆側)に

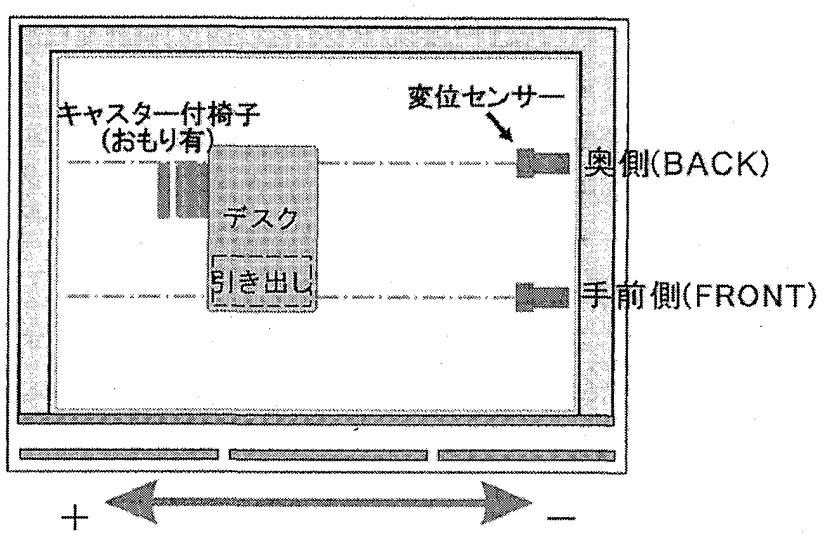

図 1 椅子付きデスク設置位置(短辺方向加振)

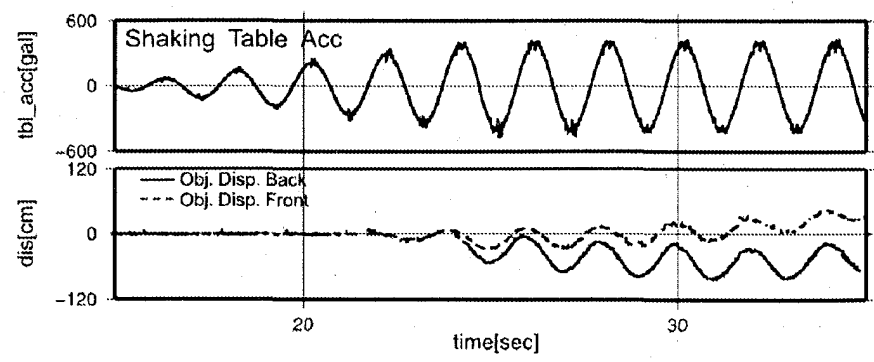

图 2 椅子付きデスク実験結果(短辺方向加振 ケース A7) 
移動しているのが見て取れる。移動量は最大で $150 \mathrm{~cm}$ 弱となった。ストッパ 一がかけられている辺が加振方向に対して平行の場合には、ストッパーを かけられている側を中心として回転しながら移動した。

\section{2.3 その他の試験体}

表 3 に振動実験の結果を示す。同表におろいて、床材にタイルカーペット を用いた場合の結果をC 列に、プライウッドを用いた場合の結果をW 列に 記載している。また、表中の○、メ、メ、は、それぞれ、試験体が移動した 場合、移動しなかった場合、転倒した場合、加振を行なっていない場合を 示している。収納棚、デスクは、椅子付デスクと同様に、試験体の長辺方向 の加振と短辺方向の加振の 2 種類行なった。表中のキャスター付家具の 「直交」と「平行」は、それぞれストッパーがかけられている辺が加振方向に 対して直交の場合と平行の場合を表している。キャスター付椅子のキャスタ 一の向きは、加振方向に対して平行に設定して加振を行なった。

タイルカーペットを用いた場合の結果 (表 3 のC列)について述べる。単 純な木箱はケース $\mathrm{A} 5 \sim \mathrm{A} 8$ で移動した。収納棚を長边方向に加振した場 合はケース A5〜A8 で移動し、短辺方向では入力加速度が 219gal のケー ス A3 では転倒せず、入力加速度が 253gal のケース A4 より大きな加速度 レベルで転倒した。キャスター付椅子は、入力加速度が 88gal のケース B2 でも移動をはじめ、加振レベルが大きくなるにつれて変位は大きくなるもの の、振動台の変位と逆方向へ移動するため、不動点のような举動をした。

プライウッドを用いた場合の結果(表 3 の W 列)をカーペットの場合の結 果(表 3 のC 列)と比較すると、単純な木箱、キャスター付椅子、キャスター 付木箱では大きな違いが見られないが、収納棚はプライウッド上の方がカ 一ペット上よりも移動または転倒を始める加振レベルがやや大きく、デスク、 椅子付デスクでは、カーペット上よりも移動し始める加振レベルが小さいこ となど、床材の影響も多少見られた。

\section{3. 振動実験のシミュレーション}

\section{1 物理シミュレーションモデルの概要}

本研究では、用体の物理シミュレーションプログラムのベースとして精密

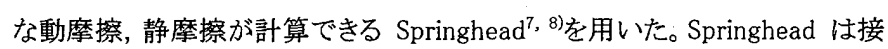

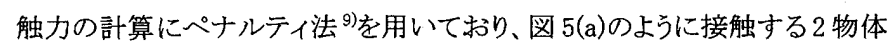
の接触領域にバネ・ダンパを設定し、2 物体の侵入量と相対速度に応じて 反力を発生させる。接触領域にバネ・ダンパを設定するという点では個別 要素法と同様である。しかし、個別要素法は接触領域に多数の要素を設 定する必要があるため計算負荷が高いのに対し、Springhead は図 5(b)のよ
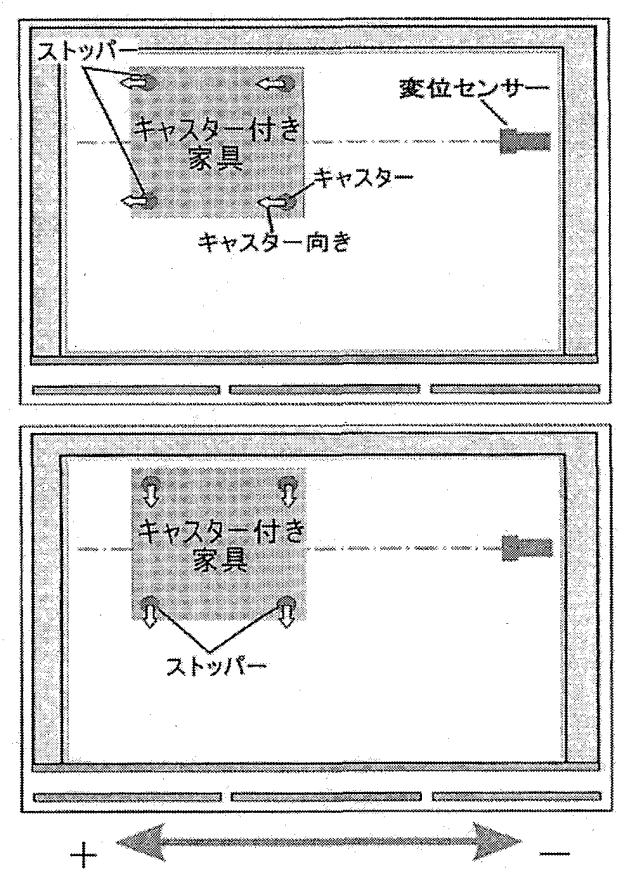

図 3 キャスター付家具設置位置

上:ストッパーがかけられている辺が加振方向に対して直交の場合, 下:平行の場合

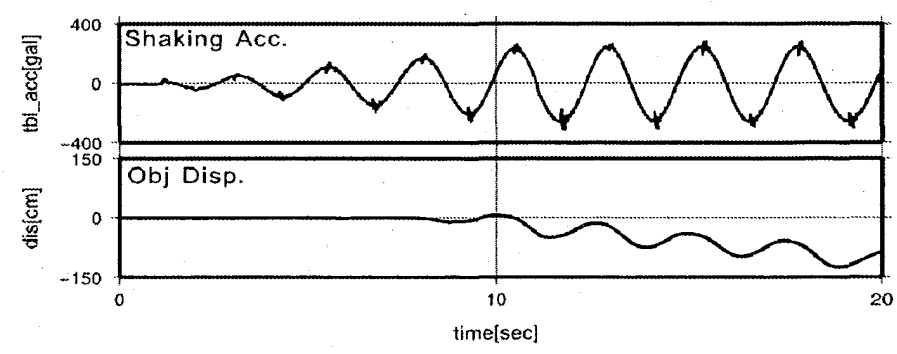

图 4 キャスター付家具害験結果

(ストッパーがかけられている辺が加振方向に対して直交 ケースA4)

うに接触領域を三角形に分割し、それぞれの三角形に対して積分して反 力を求めるため、計算時間が比較的短い。また、衝突判定にはGJKアルゴ リズム ${ }^{10}$ が用いられており、任意の凸形状の衝突を高速に検出可能である。 凹み形状については、凸形状に分割することで衝突判定を行なう。

\section{表 3 振動実験結果}

C:床材をタイルカーペットとした場合, $W$ :床材をプライウッドとした場合, $O$ :移動した, $\times$ :移動しなかった, $\triangle:$ 転倒した, 一:加振なし

\begin{tabular}{|c|c|c|c|c|c|c|c|c|c|c|c|c|c|c|c|c|c|c|c|c|c|c|}
\hline \multirow[b]{3}{*}{ ケース } & \multirow{2}{*}{\multicolumn{2}{|c|}{ 単純な木箱 }} & \multicolumn{4}{|c|}{ 収納棚 } & \multicolumn{4}{|c|}{ デスク } & \multirow{2}{*}{\multicolumn{2}{|c|}{$\begin{array}{c}\text { キャスター付椅子 } \\
\text { (おおもり無) }\end{array}$}} & \multirow{2}{*}{\multicolumn{2}{|c|}{$\begin{array}{c}\text { キャスター付椅子 } \\
\text { (おおもり有) }\end{array}$}} & \multicolumn{4}{|c|}{ キャスター付家具 } & \multicolumn{4}{|c|}{ 椅子付デスク } \\
\hline & & & \multicolumn{2}{|c|}{ 長辺方向 } & \multicolumn{2}{|c|}{ 短辺方向 } & \multicolumn{2}{|c|}{ 長辺方向 } & \multicolumn{2}{|c|}{ 短辺方向 } & & & & & \multicolumn{2}{|c|}{ 直交 } & \multicolumn{2}{|c|}{ 平行 } & \multicolumn{2}{|c|}{ 長辺方向 } & \multicolumn{2}{|c|}{ 短辺方向 } \\
\hline & $C$ & $\mathrm{~W}$ & $C$ & W & $\mathrm{C}$ & W & $\mathrm{C}$ & W & $\mathrm{C}$ & $w$ & $\mathrm{C}$ & $W$ & $C$ & W & $C$ & $W$ & $C$ & W & $\mathrm{C}$ & $w$ & $\mathrm{C}$ & $\mathrm{W}$ \\
\hline$\overline{\mathrm{A} 1}$ & $x$ & $x$ & $x$ & $x$ & - & - & $x$ & $x$ & $x$ & $x$ & 0 & - & 0 & - & 0 & 0 & 0 & 0 & $x$ & $x$ & $x$ & $x$ \\
\hline $\mathrm{A} 2$ & $x$ & $x$ & $x$ & $x$ & - & - & $x$ & $x$ & $x$ & $x$ & - & - & - & - & 0 & 0 & 0 & 0 & $x$ & 0 & $x$ & 0 \\
\hline A3 & $x$ & $x$ & $x$ & $x$ & $x$ & - & $x$ & $x$ & $x$ & $x$ & - & - & - & - & 0 & 0 & $\mathrm{O}$ & 0 & $x$ & 0 & $x$ & 0 \\
\hline A4 & $\times$ & $x$ & $x$ & $x$ & $\triangle$ & - & $x$ & $x$ & $x$ & $x$ & - & - & - & - & 0 & 0 & 0 & 0 & 0 & 0 & $x$ & 0 \\
\hline A5 & 0 & 0 & 0 & $x$ & $\triangle$ & $x$ & $x$ & $x$ & $x$ & 0 & - & - & - & - & 0 & 0 & 0 & 0 & 0 & 0 & 0 & 0 \\
\hline $\mathrm{A} 6$ & 0 & 0 & 0 & $x$ & - & $\Delta$ & $x$ & 0 & $x$ & 0 & - & - & - & - & - & - & - & - & 0 & 0 & 0 & 0 \\
\hline A7 & 0 & 0 & 0 & 0 & - & $\Delta$ & $x$ & 0 & $x$ & 0 & - & - & - & - & - & - & - & - & 0 & 0 & 0 & 0 \\
\hline $\mathrm{A} 8$ & 0 & 0 & 0 & 0 & - & - & $x$ & 0 & $\times$ & 0 & - & - & - & - & - & - & - & - & 0 & 0 & 0 & 0 \\
\hline B1 & - & - & - & - & - & - & - & - & - & - & 0 & 0 & 0 & 0 & - & $x$ & - & - & - & - & - & - \\
\hline $\mathrm{B} 2$ & - & - & - & - & - & - & - & - & - & - & 0 & 0 & 0 & 0 & - & $x$ & - & - & - & - & - & - \\
\hline B3 & - & - & - & - & $=$ & - & - & - & - & - & 0 & 0 & 0 & 0 & - & $x$ & - & - & - & - & - & - \\
\hline B4 & - & - & - & - & - & - & - & - & - & - & 0 & 0 & 0 & 0 & - & 0 & - & - & - & - & - & - \\
\hline
\end{tabular}




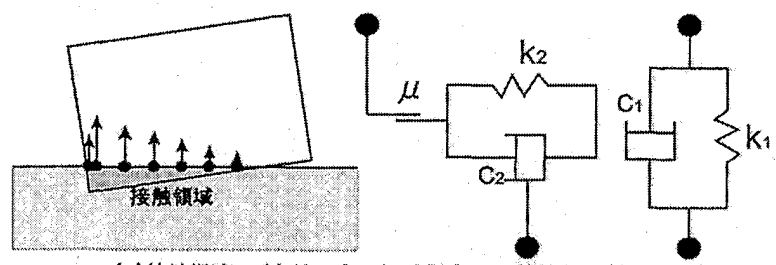

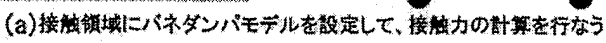

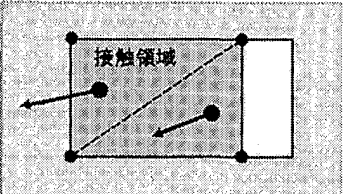

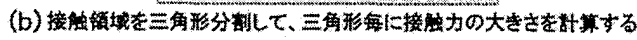

図 5 接触力の計算方法のイメージ図

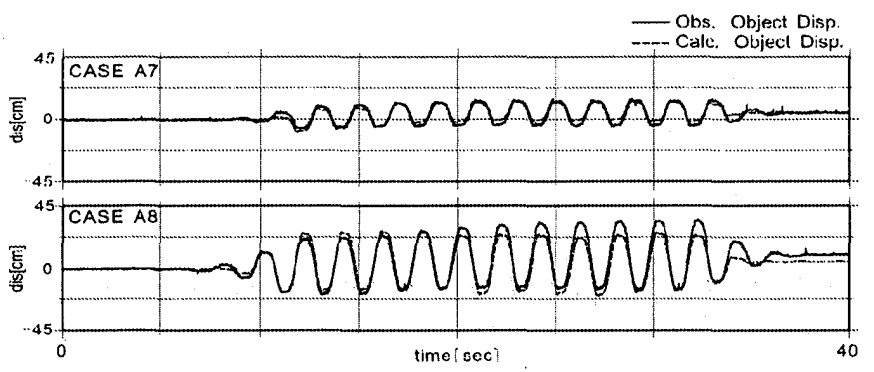

図 6 収納棚のシミュレーション結果(ケース A7, A8)

Springhead では、キャスターのような回転する機構のシミュレーションに は、Featherstoneの方法 ${ }^{11)}$ が用いられている。回転部分の制御にはPID 制 御 ${ }^{12)}$ が用いられている。PID 制御とは、各ステップにおける值と目標值との 差( $\mathrm{P}$ 制御) 、その積分(I 制御)、および微分(D 制御)に応じて制御をかける 方法である。キャスターのような自由に回転する機構は回転速度の目標值 を 0 に設定し、微小な $\mathrm{P}$ 制御, D 制御をかけることで擬似的に回転抵抗を 表現した。

シミュレーションに必要な物体の物性值は、質量、慣性テンソル、重心位 置、垂直バネ・ダンパ倸数、水平バネ・ダンパ係数、静摩擦係数、動摩擦 係数である。以後、垂直バネ・ダンパ係数、水平バネ・ダンパ係数、静摩擦 係数、動摩擦係数を合わせて表面物性值と呼ぶ。また、回転部分には P 值、D 值を設定する。振動実験のシミュレーションでは、質量, 慣性テンソ ルを除いた 9 種類のパラメータを変化させ、実験結果に合うようにパラメー タスタディを行なう。

表面物性值は試験体と床材の両方に設定する必要があり、接触力の計 算には両者の平均值が用いられる。そのため、まず床材と単純な木箱の表 面物性值を同じ值にしてパラメータスタディを行ない、それぞれの表面物 性值を決定する。他の試験体のパラメータスタディでは、床材の表面物性 值をその值に固定した上で、試験体の表面物性值のみを変化させてパラメ ータスタディを行なう。

\section{2 振動実験のシミュレーション結果}

床材がカーペットの場合の代表的な結果について述べる。収納棚を長 辺方向に加振した場合において、試験体の移動量の大きかったケース A7, A8 の実験波形とパラメータスタディ後のシミュレーション波形の比較を図 6 に示す。実線、破線がそれぞれ実験波形、シミュレーション波形であり、試 験体の振動台に対する相対変位を表している。図を見ると、ケースA7では

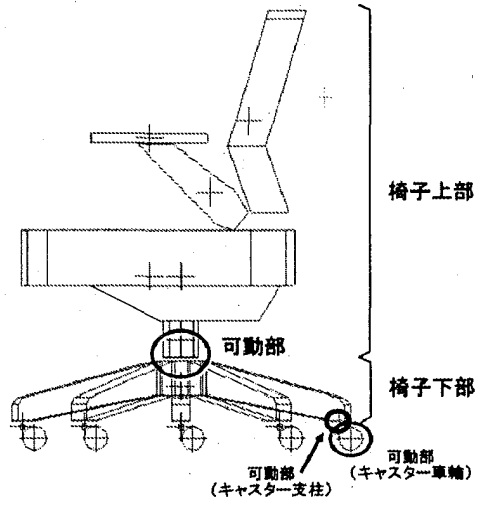

図 7 キャスター付椅子のモデル

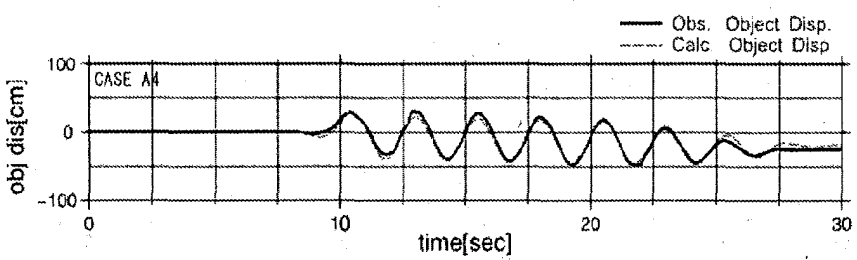

図 8 キャスター付椅子(おもり無)のシミュレーション結果(ケース A4)

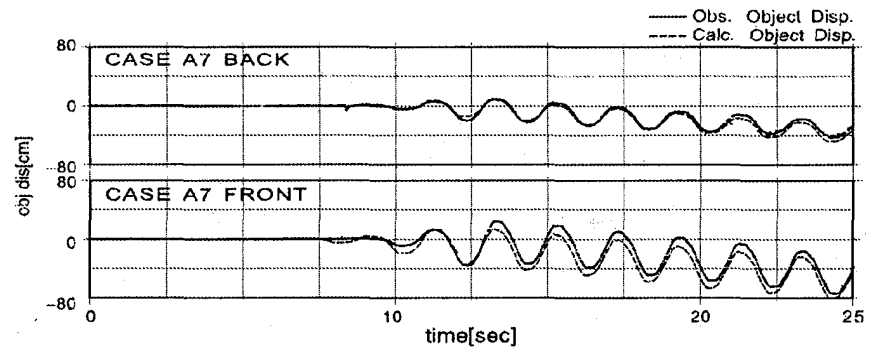

図 9 椅子付デスク(短辺方向加振)のシミュレーション結果 (ケースA7 上段: 振動台奥側, 下段: 振動台手前側)

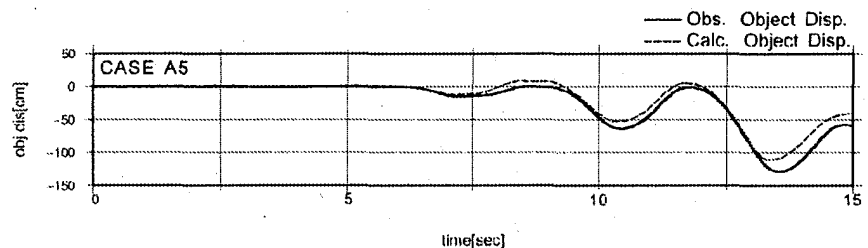

図 10 キャスター付家具のシミュレーション結果

(ストッパーがかけられている辺が加振方向に対して直交の場合

$$
\text { ケース A5) }
$$

実験波形とシミュレーション波形がほぼ一致していることがわかる。ケース A8 でも実験とシミュレーションはおおむむい一致している。なお、収納棚は時 間が経つ毎に徐々にずれていく傾向が見られたが、この举動は、モデルの 重心を中心から長辺方向へ約 $3 \mathrm{~cm}$ ずらすことで再現することができた。

図 7 にキャスター付椅子のモデルを示す。モデルは椅子上部, 下部, キ ヤスター支柱, キャスター車輪の 4 種類の㓮体で構成されており、それぞれ の境界部分に可動部を設定してある。図8にキャスター付椅子(おもり無)の ケースA4の場合におけるシミュレーション結果を示す。図をみると、実験波 
表 4 パラメータスタディにより求められた物性值

\begin{tabular}{|c|c|c|c|c|c|c|c|}
\hline & \multirow[b]{2}{*}{ カーペット } & \multirow[b]{2}{*}{ 収納棚 } & \multicolumn{5}{|c|}{ キャスター付椅子 } \\
\hline & & & 椅子上部 & 椅子下部 & キャスター支柱 & $\begin{array}{c}\text { キャスター車輪 } \\
\text { (おもり無) }\end{array}$ & $\begin{array}{c}\text { キャスタ一車輪 } \\
\text { (おもり有 })\end{array}$ \\
\hline 質量 $[\mathrm{kg}]$ & - & 130 & 5 & 6 & 0.1 & 0.1 & 0.1 \\
\hline 慣性テンソル $\left[\mathrm{kg} \cdot \mathrm{m}^{2}\right]$ & - & $\begin{array}{l}15.48,0,0 \\
0,11.05,0 \\
0,0,22.07\end{array}$ & $\begin{array}{c}6.99, \quad 2.93,-0.88 \\
2.93,15.88,-0.02 \\
-0.88,-0.02,17.17\end{array}$ & $\begin{array}{l}0.09,0,0 \\
0,0.17,0 \\
0,0,0.09\end{array}$ & $\begin{array}{c}5.69 \times 10^{-5},-2.68 \times 10^{-7}, 7.75 \times 10^{-7}, \\
-2.68 \times 10^{-7}, 5.46 \times 10^{-5}, 1.07 \times 10^{-5}, \\
7.75 \times 10^{-7}, 1.07 \times 10^{-5}, 1.18 \times 10^{-5},\end{array}$ & $\begin{array}{l}2.32 \times 10^{-5}, 0,0 \\
0,2.24 \times 10^{-5}, 0 \\
0,0,2.24 \times 10^{-5}\end{array}$ & $\begin{array}{l}2.32 \times 10^{-5}, 0,0 \\
0,2.24 \times 10^{-5}, 0 \\
0,0,2.24 \times 10^{-5}\end{array}$ \\
\hline 重直バネ $[\mathrm{N} / \mathrm{m}]$ & $1.6 \times 10^{5}$ & $1.6 \times 10^{7}$ & - & - & - & $1.2 \times 10^{6}$ & $1.2 \times 10^{6}$ \\
\hline 垂直ダンパ $[\mathrm{N} \cdot \mathrm{s} / \mathrm{m}]$ & $3.2 \times 10^{5}$ & $3.2 \times 10^{5}$ & - & - & - & $4.0 \times 10^{2}$ & $4.0 \times 10^{2}$ \\
\hline 水平バネ $[\mathrm{N} / \mathrm{m}]$ & $2.8 \times 10^{4}$ & $2.8 \times 10^{5}$ & - & - & - & $2.8 \times 10^{4}$ & $2.8 \times 10^{4}$ \\
\hline 水平ダンパ $[\mathrm{N} \cdot \mathrm{s} / \mathrm{m}]$ & $2.8 \times 10^{5}$ & $2.8 \times 10^{5}$ & - & - & - & $2.8 \times 10^{5}$ & $2.8 \times 10^{5}$ \\
\hline 棦止摩搳係数 & 0.33 & 0.34 & - & - & - & 0.60 & 0.40 \\
\hline 動摩擦係数 & 0.31 & 0.34 & - & - & - & 0.40 & 0.20 \\
\hline $\mathrm{P}$ 值, D 值 & - & - & - & $2.0,0.0$ & $1.0 \times 10^{-4}, 1.0 \times 10^{-5}$ & $1.05 \times 10^{-3}, 1.0 \times 10^{-5}$ & $1.0 \times 10^{-4}, 1.0 \times 10^{-5}$ \\
\hline
\end{tabular}

\begin{tabular}{|c|c|c|c|c|}
\hline & & & キャスター1 & 家具 \\
\hline & T人ク & 木箱 & キャスター車輪 & ストッパーをかけたキャスター \\
\hline 質量 [kg] & 71 & 110 & 0.1 & 0.2 \\
\hline 慣性テンソル[kg・m²] & $\begin{array}{c}6.99,2.93,-0.88 \\
2.93,15.88,-0.02 \\
-0.88,-0.018,17.17\end{array}$ & $\begin{array}{l}17.12,0,0 \\
0,7.75,0 \\
0,0,17.12\end{array}$ & $\begin{array}{l}2.32 \times 10^{-5}, 0,0 \\
0.2 .24 \times 10^{-5}, 0 \\
0,0,2.24 \times 10^{-5}\end{array}$ & $\begin{array}{l}1.60 \times 10^{-4},-2.68 \times 10^{-7}, 7.75 \times 10^{-7}, \\
-2.68 \times 10^{-7}, 1.17 \times 10^{-4}, 5.07 \times 10^{-5} \text {, } \\
7.75 \times 10^{-7}, 5.07 \times 10^{-5}, 7.43 \times 10^{-5}\end{array}$ \\
\hline 垂直バネ $[\mathrm{N} / \mathrm{m}]$ & $1.6 \times 10^{6}$ & - & $1.2 \times 10^{6}$ & $1.2 \times 10^{6}$ \\
\hline 垂直ダンパ[N·s/m] & $3.2 \times 10^{4}$ & - & $4.0 \times 10^{2}$ & $4.0 \times 10^{2}$ \\
\hline 水平バネ $[\mathrm{N} / \mathrm{m}]$ & $2.8 \times 10^{5}$ & - & $2.8 \times 10^{5}$ & $2.8 \times 10^{4}$ \\
\hline 水平ダンパ $[\mathrm{N} \cdot \mathrm{s} / \mathrm{m}]$ & $2.8 \times 10^{3}$ & - & $2.8 \times 10^{5}$ & $2.8 \times 10^{5}$ \\
\hline 髅止摩擦係数 & 0.70 & - & 0.40 & 0.40 \\
\hline 動摩擦係数 & 0.35 & - & 0.15 & 0.15 \\
\hline P值, D 值 & - & - & $1.0 \times 10^{-5}, 1.0 \times 10^{-5}$ & $1.0 \times 10^{-4}, 1.0 \times 10^{-5}$ \\
\hline
\end{tabular}

形とシミュレーション波形はよく一致しているのがわかる。ただし、150gal 程 度より小さい加振ケースについては試験体の動きを過大評価する場合も見 られた。この原因としては、静止時には、キャスターはカーペット表面の毛 の中に沈んでいるため、動き始めの回転抵抗が大きくなるものと予想される が、シミュレーションではこれが考慮されていないためと考えられる。試験体 が移動し始める際にキャスターの回転抵抗を変化させるなどの工夫をすれ ば、より精度よくシミュレーションを行なえる可能性がある。

椅子付デスクのモデルは、デスクの天板とキャスター付椅子の时掛けの 間にバネ・ダンパを設定し、結合することで作成した。図 9 に椅子付デスク (短辺方向)のケース A7 の場合におけるシミュレーション結果を示す。上段， 下段の図はそれぞれ振動台奥側と手前側の振動台に対する相対変位を 表している。図を見ると、実験波形とシミュレーション波形が概ね一致して おり、水平方向に回転しながら移動している様子が再現できているのがわ かる。

図 10 にストッパーがかけられている辺が加振方向に対して直交の場合 におけるキャスター付家具のケース A5 におけるシミュレーション結果を示 す。図を見ると、実験波形とシミュレーション波形は比較的一致しており、ス トッパーがかけられた側とは逆側(負の方向)に徐々に移動している様子が シミュレートできているのがわかる。

表 4 に以上のパラメータスタディにより求められたカーペットと収納棚、キ ヤスター付椅子(おもり有, 無)、椅子付デスク、キャスター付家具の物性值 を示す。なお、質量と慣性テンソルは、物体の重さや形状から求められたも のである。

\section{4. 家具群のシミュレーション}

\section{1 家具群のシミュレーション概要}

振動台実験では加振の強さは振動台の性能に限定されてしまい、また、
加振できるスペースも限られている。そのため、振動台実験では不可能な 入カレベルの摇れや大空間における複数の家具群の動きをシミュレートレ、 超高層建物上階でのそれらの挙動について考察する。

シミュレーションモデルは、図 12 の上段のようになっており、部屋の広さ は約 $90 \mathrm{~m}^{2}$ である。設定した家具はデスク単体が 10 個、キャスター付椅子 (おもり無)が 10 個、椅子付デスクが 12 個、收納棚が 5 個、キャスター付家 具が 1 個である。オフィスで用いられている一般的なレイアウトを参考に家 具の配置を行なった。図に示すように、各デスクの列の端には収納棚を配 置し、中央の列には収納棚とキャスター付家具を配置した。キャスター付家 具のストッパーは南側の 2 籄所にかけた。デスク単体と椅子付デスクはラン ダムに配置した。

なお、家具群のシミュレーションでは、家具同士の衝突も発生する。衝突 の取り扱いは、図5に例示した物体と床の接触時の処理法と基本的に同様 である。物体間の衝突に関連する物性值は、振動実験からは得られていな いが、Springhead では物体同士の衝突に対するバネ・ダンパ等のパラメー タがデフォルト值で与えられており、これを参考にして、重量が大きく異なる 物体同士(キャスター付椅子と収納棚)の衝突後の挙動が安定するように パラメータを微調整した。

30 階程度の超高層建物を想定して、入力波形には東海地震の新宿で のシミュレーション波形 ${ }^{2)}$ から求めた 1 質点系の絶対速度応答波(減衰 $5 \%$, 固有周期 $2.5 \mathrm{sec}$ )を用い、水平 2 方向加振を行なう。シミュレーション波形と その応答波を図 11 に示す。上の 2 つの図がシミュレーション波形の NS， EW 成分で、下の 2 つの図が 1 質点系の絶対速度応答波の NS, EW 成分 である。NS成分では、約 30 秒の時点に 180kine 程度、約 90 秒の時点に 120kine 程度の大きい速度振幅が生じていることがわかる。なお、絶対変位 忘答の最大振幅は約 $100 \mathrm{~cm}$ である。 

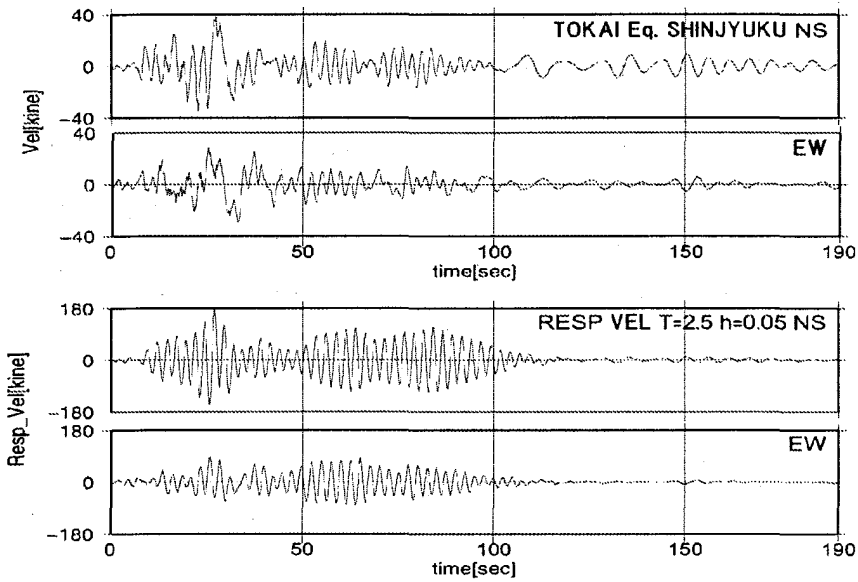

図 11 東海地震のシミュレーション波形(上段)とその応答波(下段)

\section{2 家具群のシミュレーション結果}

図 12 に家具群のシミュレーション結果を示す。図は上から 0 秒後, 30 秒 後, 90 秒後の様子を示している。最初にキャスター付椅子とキャスター付 家具が動きはじめ、その後、椅子付デスクが動き始めた。全ての収納棚が 約 20 秒後の時点でロッキングをはじめ、その後転倒した。キャスター付家 具は、隣接する椅子付デスクに何度も衝突し、その椅子付デスクは押され て移動した。

入力波の振幅がほぼ最大になった 30 秒後の時点(最大変位で約 $100 \mathrm{~cm}$ )で、キャスター付椅子(おもり無)は一度に最大で約 $100 \mathrm{~cm}$ 移動し、 キャスター付家具は約 $60 \mathrm{~cm}$ 、椅子付デスクは約 $40 \mathrm{~cm}$ 、デスク単体は約 $20 \mathrm{~cm}$ 弱移動し、元のレイアウトがかなり崩れていることがわかる。

90 秒後は応答波の 2 回目のピークが生じている時点で、家具群の移動 の繰り返しにより、家具群がさらに散らばっていることがわかる。最終的に、 キャスター付椅子(おもり無)は累積で最大約 $130 \mathrm{~cm}$ 移動し、キャスター付

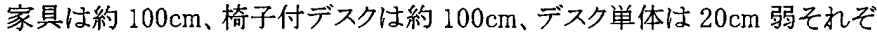
れ移動した。

家具群の移動の繰り返しは約 80 秒間続き、このような状況の下では、人 は立っていられず、恐怖感が大きいため、避難することは困難になるものと 思われる。さらに、周りの家具に衝突したり、移動した家具にはさまれたり寸 ることにより、怪我をする可能性も高いものと推察される。

既往の研究例えは、3)-6)では、短周期成分が卓越する高加速度の地震動を 対象とし、家具類の举動はもつぱら転倒・ロッキングに主眼がおかれており、 このような家具類の大きな移動には十分な関心が向けられていなかった。 長周期・大振幅の地震動に摇さぶられる建物内の室内居住空間の安全性 や避難行動を可否を検討するためには、従来から対象とされてきた家具類 の転倒に加え、家具類の移動、特にキャスター付の家具類の移動の定量 的な評価が重要であることが理解できる。

\section{5. 楛諭}

超高層建物上階で発生する長周期・大振幅の摇れによる建物内部の家 具類の举動について険討した。まず、振動台実験を行なって試験体単体 の举動を把握した。デスク単体では最も加速度レベルの大きい加振ケース でも移動しなかったが、人がキャスターの椅子に座ったまま机にしがみつ いた場合を想定した椅子付デスクは、より小さい加速度でも移動することが
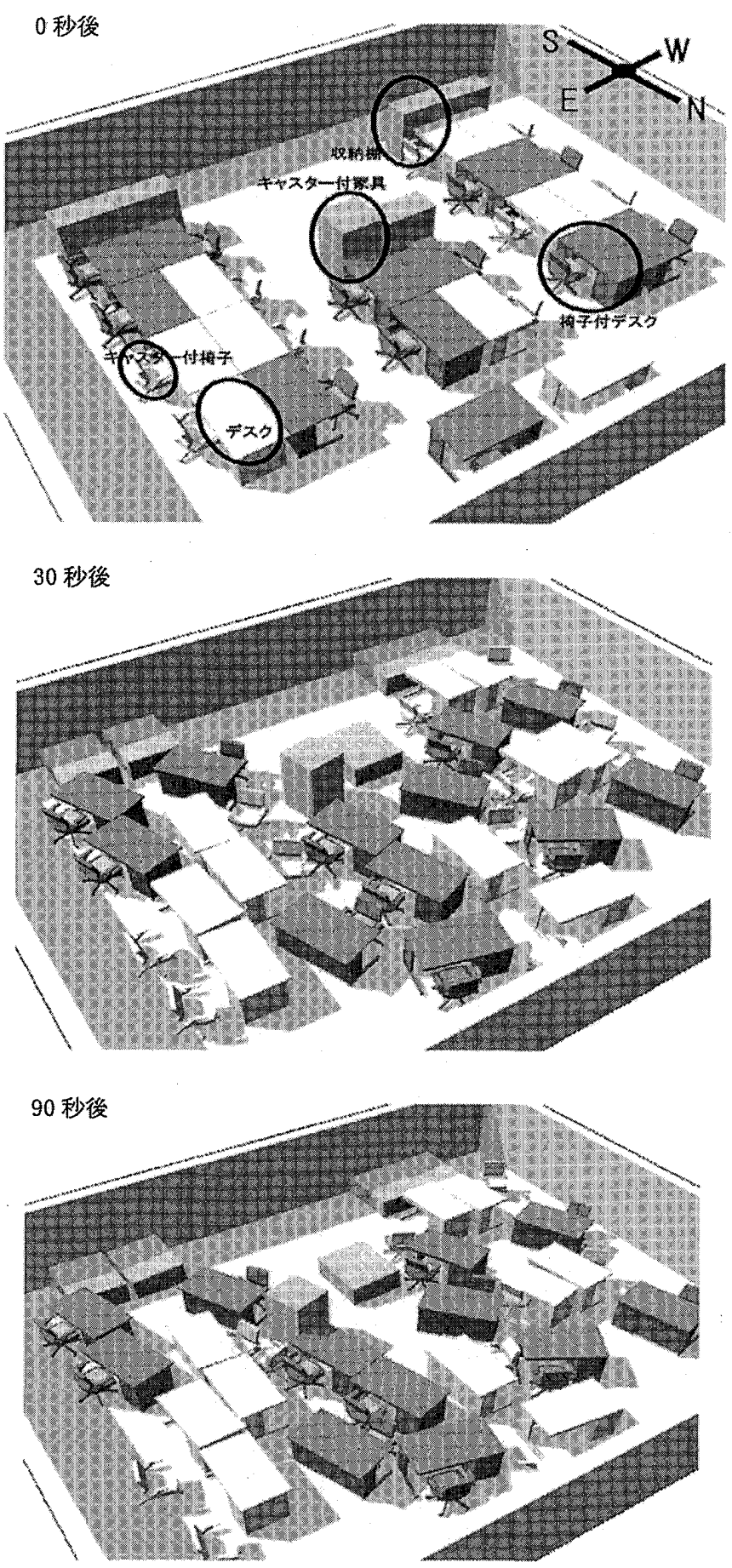

図 12 家具群のシミュレーション結果

わかった。キャスター付家具については、ストッパーの位置により異なる举 動が見られた。

次に、Springhead をベースとした㓮体の物理シミュレーションプログラム を用いて、振動実験のシミュレーションを行ない、摩擦倸数等のパラメータ の設定を行なった。その結果、可動部を多数持つキャスター付椅子や複雑 な挙動をする椅子付デスク等を含めて振動実験での挙動を概ねよく再現 できることを確認した。

最後に、そのパラメータを用いてオフィス空間を再現し、仮想東海地震 における新宿でのシミュレーション波形を用いて, 超高層建物上階での家 具群の挙動をシミュレートした。その結果、主要動が続く約 80 秒の間、家 
具類は大きく移動し衝突を繰り返すため、恐怖感を感じ、避難も困難で家 具類の転倒や移動により怪我をする可能性が高い状況になることが推測さ れた。特に、長周期・大振幅の地震動が引き起こす家具類の移動は、これ まで十分な関心が向けられていなかった挙動であり、地震時の室内居住空 間の安全性を適切に評価するために、定量的な検討が重要である。

\section{謝辞}

長谷川昌一助教授(電気通信大学)には、物理シミュレータについて貴 重なご助言をいただいた。また、実験に用いた試験体はコクヨファニチャー 株式会社より提供して頂いたものである。記して謝意を表する。なお、本研 究は、文部科学省特別教育研究経費「首都圈大震災軽减のための実践 的都市地震工学研究の展開」(研究代表者:東京工業大学大町達夫)の 一環として実施された。

\section{参考文南}

1）東京消防庁：家具類の転倒・落下防止対策ハンドブック－室内の地震対策2006 .

東海地震等巨大地震への対応特別委員会：巨大地震による長周期地震動の 予测と既存建筑物の耐震性と今後の課題, 日本建築学会, 2006 .

3) Ishiyama, Y.: Criteria for Overturning of Bodies by Earthquake Excitations, Trans. of A.J.J., No.317, pp.1-14, 1982.

4）岡田成幸：地震時の室内変容に伴亏人的被害危険度評価に関する研究 一そ の 1 居住空間危険度マイクロゾーニングの提案-, 日本建築学会構造系論文 報告集, No.454, pp.39-49, 1993.
5）翠川三郎, 佐藤俊明: 1993 年釧路沖地震での釧路市役所拉よび釧路気象台 での家具の転倒調查 -家具転倒率と床応答の関倸-, 日本建築学会構造系 論文報告集, No. 469, pp.53-60, 1995.

6）金子美香, 林 康裕: 㓮体の転倒率曲線の提案, 日本建築学会構造系論文報 告集, No.536, pp.55-62, 2000.

7）長谷川晶一, 藤井伸旭, 赤羽克仁, 小池康晴, 佐藤 誠: カ覚インタラクション のための多面体の接触体積に基づく実時間㓮体運動シミュレーション, 計测自 動制御学会論文集, Vol.40, No.2, pp.122-131, 2004.

8) Hasegawa, S. and Sato, M.: Real-time Rigid Body Simulation for Haptic Interactions Based on Contact Volume of Polygonal Objects, Eurographics 2004, Vol.23, pp.529-538, 2004.

9) Erleben, K., Sporring, J., Henriksen, K. and Dohlmann, H.: Physics-Based Animation, Charles River Media Inc., 2005.

10) Gilbert, E. G., Johnson, D. W., and Keerthi, S. S.: A Fast Procedure for Computing the Distance Between Complex Objects in Three-dimensional Space, IEEE Journal of Robotics and Automation, Vol.4, No.2, pp.193-203, 1988.

11) Featherstone, R.: The Calculation of Robot Dynamics Using Articulated-body Inertias, International Journal of Robotics, Research, Vol.2, No.1, pp.13-30, 1983.

12）山本重彦, 加藤尚武: PID 制御の基礎と応用(第 2 版), 朝倉書店, 2005 .

(2007年 5 月 9 日原稿受理, 2007年 7 月 4 日採用決定) 